\title{
HUBUNGAN FAKTOR RESIKO HIGIENE DENGAN KEJADIAN TINEA PEDIS
}

\author{
Dessy Marianti Marila ${ }^{\bowtie}$, Alexander P. Marpaung, Renatha Nainggolan \\ Fakultas Kedokteran, Universitas Methodist Indonesia, Medan, Indonesia \\ Email: mariladessy@gmail.com
}

DOI: https://doi.org/10.46880/methoda.Vol11No1.pp48-52

\begin{abstract}
Tineapedis is not a life-threatening disease, its clinical form can last for years without significant complaints, but tineapedis can be a big problem if secondary infection (bacterial infection) has appeared with symptoms ranging from mild (rash - red rash that is sore) to more severe such as pain and fever. The itching that is caused every day because of tineapedis can also interfere with a person's activities or work so that it will reduce the quality of his life. In Indonesia, during 2000-2004, the prevalence increased by 14.4\%. In Indonesia, based on data from reports in all hospitals in 2010, there were 122,076 new cases of skin infections in which tineapedis was included. Apart from wearing closed shoes for a long time, increased humidity due to sweating, mechanical rupture of the skin, level of personal hygiene, and exposure to fungi are risk factors that cause tineapedis. The purpose of this study was to analyze the relationship between hygiene risk factors and the incidence of tineapedis. This research is a type of analytic research using a literature review system by using comparisons and equations between several journals that have been selected. From the six journals that have been collected and analyzed, it can be concluded that the hygiene factor is the main risk factor for the occurrence of TineaPedis. For the journal AstritNapitupulu which contradicts other journals which states that hygiene factors do not affect the incidence of tineapedis where the effect is the use of antiseptic soap. Meanwhile, for the journal KaruniaPratama, Rustika, FadlilaMuhtadin, HeruLaksono, SantriadiHadi stated that the hygiene factor is the factor that causes tineapedis which consists of washing feet, changing socks and shoes which are the specific objectives of this thesis. The main cause of tineapedis is Trycophyton Rubrum. There is a relationship between risk factors for hygiene and the incidence of tineapedis.
\end{abstract}

Keywords: Hygiene and TineaPedis.

\begin{abstract}
ABSTRAK
Tinea pedis bukan penyakit yang mengancam jiwa, bentuk klinisnya bisa bertahuntahun tanpa keluhan berarti, namun tinea pedis dapat menjadi masalah yang besar apabila telah muncul infeksi sekunder (infeksibakteri) dengan gejala mulai dari yang ringan (bintil - bintil merah yang perih) hingga yang lebih berat seperti nyeri dan demam. Rasa gatal yang ditimbulkan setiap hari akibat dar itinea pedis juga bisa mengganggu aktivitas atau pekerjaan seseorang sehingga akan menurunkan
\end{abstract}


kualitas hidupnya. Di Indonesia sendiri pada tahun 2000 - 2004 prevalensinya mengalami peningkatan 14,4\% . Di Indonesia berdasarkan data laporan di seluruh rumah sakit tahun 2010 menunjukanangka 122.076 kasus baru untuk penyakit infeksi kulit dimana tinea pedis termasuk didalamnya. Selain karena pemakaian sepatu tertutup untuk waktu yang lama, bertambahnya kelembaban karena keringat, pecahnya kulit karena mekanis, tingkat kebersihan perorangan, dan paparan terhadap jamur merupakan faktor resiko yang menyebabkan terjadinya tinea pedis. Tujuan penelitian ini adalah menganalisis hubungan faktor resiko higiene dengan kejadian tinea pedis. Penelitian ini merupakan jenis penelitian analitik mengunakan system literature review dengan mengunakan perbandingan dan persamaan antara beberapa jurnal yang telah dipilih. Dari keenam jurnal yang telah dikumpulkan dan dilakukan analisis maka dapat di tarik kesimpulan bahwa faktor higiene merupakan faktor resiko paling utama penyebab terjadinya Tinea Pedis. Untuk jurnal Astrit Napitupulu yang bertentangan dengan jurnal lainnya yang menyatakan bahwa faktor higiene tidak memperngaruhi kejadian tinea pedis dimana yang berpengaruh adalah pengunaan sabun antiseptik. Sementara untuk jurnal Karunia Pratama, Rustika, Fadlila Muhtadin, Heru Laksono, Santriadi Hadi menyatakan bahwa faktor higiene yang merupakan faktor yang menjadi penyebab terjadininya tinea pedis yang terdiri dari kebiasaan mencuci kaki, kebiasaan mengganti kaus kaki dan sepatu yang merupakan tujuan khusus dari skripsi ini. Serta untuk penyebab utama yang paling sering kejadian tinea pedis adalah TrycophytonRubrum. Adanya hubungan antara faktor resiko higiene dengan kejadian tinea pedis.

Kata Kunci: Higiene dan Tinea Pedis.

\section{PENDAHULUAN}

Tinea pedis bukan penyakit yang mengancam jiwa, bentuk klinisnya bisa bertahun-tahun tanpa keluhan berarti, namun tinea pedis dapat menjadimasalah yang besar apabila telah munculi nfeksi sekunder (infeksi bakteri) dengan gejala mulai dari yang ringan (bintil-bintil merah yang perih) hingga yang lebih berat seperti nyeri dan demam. Rasa gatal yang ditimbulkan setiap hari akibat dari tinea pedis juga bisa mengganggu aktivitas atau pekerjaan seseorang sehingga akan menurunkan kualitas hidupnya (Natalia, Pratiwi, \& Fakihun, 2018).

Tinea pedis terdapat di seluruh dunia sebagai dermatofitosis yang paling sering terjadi. Dermatomikosis superfisialis merupakan jenisinfeksi yang paling sering terjadi, dimana telah mengenai 20-25\% populasi dunia (WHO, 2013). Tinea pedis menginfeksi sekitar $10 \%$ populasi dunia. Tineapedis dapat menginfeksi daerah tumit, sela-sela jari, dan telapak kaki. Infeksi tinea pedis dapat menyebar kedaerah lain termasuk kuku yang bisa menjadi sumber infeksi kedaerah lainnya. (Napitupulu, Subchan, \& Widodo, 2016). Di berbagai negara angka kejadiannya bervariasi, di negara maju seperti Italia sebesar 20,4\% sesuai data dari RumahSakit Bari Policclinico tahun 2005 - 2010. Di negara negara berkembang seperti di Garhwal Himalayan India sebesar 18,92 \%. Prevalensi penyakit dermatofitosis di Asia mencapai 35,6\%. Di Indonesia sendiri pada tahun 2000 - 2004 prevalensinya mengalami peningkatan 14,4\%. Di Indonesia berdasarkan data laporan di seluruhrumah sakit tahun 2010 menunjukan angka 122.076 kasus baru untuk penyakit infeksi kulit dimana tinea pedis termasuk didalamnya 
(Kemenkes RI, 2011). Dari keseluruhan insidensi berhubungan pekerja dengan pekerjaan, sehingga sering disebut dermatofitosis akibat kerja antara lain tinea pedis.(Arjana, 2018).

Angka kejadian tinea pedis lebih tinggi di daerah beriklim panas dan lembab serta berpenduduk padat. Indonesia memiliki iklim tropis dengan begitu sangat mendukung untuk penyebaran infeksi tinea pedis. Selain iklim panas dan lembab, pemakaian sepatu meningkatkan risiko infeksi di kaki. Di Indonesia tinea pedis tidak banyak ditemukan, kecuali pada populasi tertentu yang menggunakan sepatu tertutup dan kaos kaki yang lama (Larasati, 2017).

Selain karena pemakaian sepatu tertutup untuk waktu yang lama, bertambahnya kelembaban karena keringat, pecahnya kulit karena mekanis, tingkat kebersihan perorangan, dan paparan terhadap jamur merupakan faktor resiko yang menyebabkan terjadinya tinea pedis. Tinea pedis lebih banyak pada daerah tropis serta iklim yang panas dapat memperburuk kondisi penyakit tersebut. Udara yang panas dan lembab serta sepatu yang sempit sering mempermudah infeksi tersebut. Orang yang memakai sepatu ke sekolah dari pagi, siang sampai sore hari setiap hari-(Farihatun, 2018).

\section{METODE PENELITIAN}

Metode penelitian yang digunakan adalah Literature Review, dengan menggunakan data sekunder. Data dikumpulkan dengan menggunakan teknik dokumentasi. Jurnal penelitian yang digunakan adalah 6 jurnal dengan kriteria inklusi tanggal publikasi 5 tahun terakhir, bahasa yang digunakan bahasa indonesia atau bahasa inggris, dengan subjek penelitian Hubungan Faktor Higiene dengan Kejadian Tinea Pedis, dan publikasi full text.

\section{HASIL DAN PEMBAHASAN}

Tinjauan Pustaka ini menjelaskan bukti yang dipublikasi mengenai kemungkinan faktor-faktor yang mempengaruhi penelitian hubungan faktor higiene dengan kejadian tinea pedis. Higiene adalah faktor penting yang akan mempengaruhi seseorang tersebut, mengalami tinea pedis dan beberapa faktor yang berhubungan dengan higiene, antara lain adalah kebiasaan mencuci kaki, kebiasaan mengganti kaus kaki dan sepatu, mencuci kaos kaki dan sepatu dan beberapa faktor lain.

Tabel 1. Tabel Penelitian Terdahulu

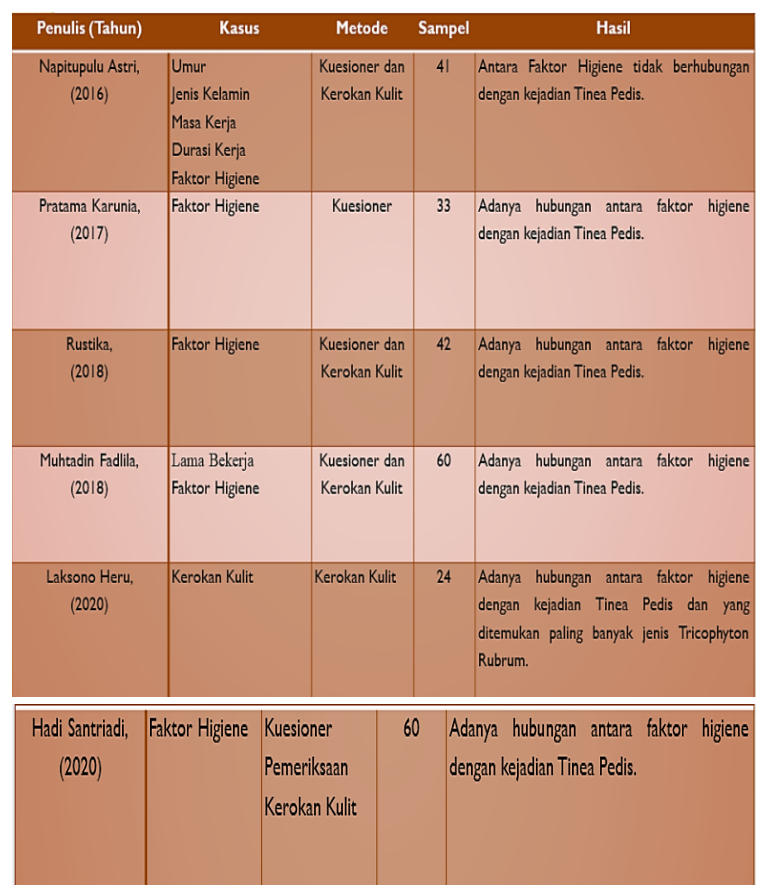

Berdasarkan penelitian yang dilakukan oleh Astri Napitupulu, 2016 yang dilakukan dengan mengunakan kuesioner yang telah divalidasi dilanjutkan dengan pemeriksaan kerokan kulit maka di dapatkan angka kejadian tinea pedis pada polisi lalulintas Kota Semarang sebesar 41,5\%. Dalam penelitian yang dilakukan menjelaskan bahwa lama memakai sepatu tertutup mempengaruhi angka kejadian tinea pedis ( $p$ $=0,024$ ) sementara untuk faktor higiene kurang berpengaruh dalam angka kejadian tinea pedis yang memiliki dampak terhadap kejadian tineapedis $(p=0,067)$ hanya point 
pengunaansabun anti septik $(\mathrm{p}=0,008)$ (Napitupulu et al., 2016).

Berdasarkan penelitian Karunia Friska Pratama, 2017 dengan mengunakan anamnesa atau wawan cara dilanjutkan dengan pemeriksaan fisik, pengisian lenbaran kuesioner pada 33 orang yang yang diambil dengan cara simple random sampling. Dalam penelitian ini didapatkan bahwa pemakain APD pada saat bekerja yang lengkap dapat mengurangi angka kejadian tinea pedis dibarengi dengan peningkatan faktor higiene seperti kebersihan kulit, kebersihan tangan, kuku dan kaki akan menurunkan angka kejadian dari seseorang tersebut mengalami tinea pedis (Pratama, 2017).

Berdasarkan penelitian Fadlila dkk, 2018 berdasarkan hasil, hal ini membuktikan bahwa memang lamanya bekerja pada nelayan merupakan faktor predisposisi yang dapat memicu terjadinya infeksi tinea pedis sebagaimana, nelayan adalah salah satu contoh okupasi yang kesehariannya bekerja di air menggunakan sepatu tertutup dengan waktu yang cukup lama dan sering. Ruang lingkup kerja mereka juga seputar daerah, panas dan lembab. Hal-hal tersebut merupakan beberapa faktor yang memudahkan timbulnya infeksi jamur pada kaki atau Tinea pedis. Kondisi ini akan semakin diperparah apabila para nelayan tersebut kurang memperhatikan kebersihan dirinya masing-masing terutama tidak selalu mencuci kaki setelah mereka selesai bekerja. Pada penelitian yang dilakukan dengan wawancara serta mengisi kuesione serta pemeriksaan kulit didapatkan bahwa adanya hubungan antara faktor higiene dengan angka kejadian tinea pedis (Muhtadin \& Latifah, 2018).

Berdasarkan penelitian yang dikakukan Rustikadkk, 2018 dengan sampel sebanyak 42 orang yang dipilih dengan teknik stratified random sampling untuk mendapatkan sampel yang proporsional dimana pengumpulan data dilakukan dengan wawancara, observasi, dan pemeriksaan mikroskopis. Pengunaan APD dinilai dari kebiasaan memakai sepatu atau kaos kaki selama bekerja, dan mencuci kaki setelah bekerja didapatkan bahwa antara higiene dan tinea pedis saling berhubungan satu sama lain (Rustika \& Agung, 2018).

Berdasarkan penelitian Heru Laksono $\mathrm{dkk}, 2020$ prevalensi kejadian tinea pedis pada wanita pembelah ikan di Perkampungan Nelayan Kota Bengkulu Tahun 2018 adalah sebesar 37,5\%. Beberapa faktor yang diduga sebagai faktor risiko adalah penggunaan sepatu boot, menggunakan kaos kaki, kebiasaan mencuci kaki dan lama bekerja (Laksono, Yunita, \& Utari, 2020).

Berdasarkan penelitian yang dilakukan oleh Santriadi Hadi, 2020 yang dilakukan terhadap 60 mahasiswa tamtama. Data dikumpulkan dengan teknik wawancara, pengisian kuesioner dan pemeriksaan kerokan kulit didapatkan bahwa pemakaians epatu yang tertutup dalam jangka waktu yang lama serta faktor higiene yang terdiri dari kebersihan kulit dan handuk dapat meningkatkan angka kejadian yang berhubungan dengan tinea pedis $(\mathrm{p}=0.000)$ (Hadi, 2020).

Dari keenam jurnal yang telah dikumpulkan dan dilakukan analisis maka dapat di tarik kesimpulan bahwa faktor higiene merupakan faktor resiko paling utama penyebab terjadinya Tinea Pedis. Untuk jurnal Astrit Napitupulu yang bertentangan dengan jurnal lainnya yang menyatakan bahwa faktor higiene tidak memperngaruhi kejadian tinea pedis dimana yang berpengaruh adalah pengunaan sabun antiseptik. 
Sementara untuk jurnal Karunia Pratama, Rustika, Fadlila Muhtadin, Heru Laksono, Santriadi Hadi menyatakan bahwa faktor higiene yang merupakan faktor yang menjadi penyebab terjadinya tinea pedis yang terdiri dari kebiasaan mencuci kaki, kebiasaan menggant ikaus kaki dan sepatu yang merupakan tujuan khusus. Serta untuk penyebab utama yang paling sering kejadian tinea pedis adalah TrycophytonRubrum.

\section{KESIMPULAN}

Berdasarkan alisis jurnal yang telah dilakukan maka di dapatkan bahwa lama bekerja serta memakai sepatu yang tertutup dibarengi dengan faktor higiene yang kurang merupakan faktor utama yang menyebabkan Tinea Pedis dan penyebab terbanyaknya adalah jenis Tricophyton Rubrum.

\section{DAFTAR PUSTAKA}

Arjana, I. K. (2018). Hubungan Pemakaian Alat Pelindung Diri (APD) Dengan Kejadian Tinea Pedis Pada Petani Buah dan Sayur Di Wilayah Kerja UPT Puskesma Bangli Utara,Bangli Bali. Universitas Jember.

Farihatun, A. (2018). IDENTIFIKASI JAMUR PENYEBAB TINEA PEDIS PADA KAKI PENYADAP KARET DI PTPN VIII CIKUPA DESA CIKUPA KECAMATAN BANJARSARI KABUPATEN CIAMIS TAHUN 2017. Meditory : The Journal of Medical Laboratory, 6(1), 56-60. https://doi.org/10.33992/m.v6i1.236

Hadi, S. (2020). Faktor yang Berhubungan dengan Kejadian Tinea Pedis pada Mahasiswa Tamta di Resimen Induk Kodam VII Wirabuana Makassar. UMI Medical Journal, 5(1), 12-19.

Laksono, H., Yunita, N., \& Utari, S. (2020). PREVALENSI KEJADIAN TINEA PEDIS PADA WANITA PENGOLAH IKAN DI PEMUKIMAN NELAYAN KOTA BENGKULU TAHUN 2018. Journal of Nursing and Public Health,

$$
\text { 8(1), 43-47. }
$$

Larasati, N. (2017). GAMBARAN DAN

FAKTOR RISIKO TINEA PEDIS

PADA TENTARA DI PUSAT

PENDIDIKAN INFANTERI

$B A N D U N G$. Universitas Jenderal

Ahmad Yani.

Muhtadin, F., \& Latifah, I. (2018). Nelayan

Di Pulau Panggang Kepulauan Seribu.

Jurnal Ilmiah Kesehatan, 10(1), 103109.

Napitupulu, A. N., Subchan, P., \& Widodo, Y. L. A. (2016). Prevalensi Dan Faktor Risiko Terjadinya Tinea Pedis Pada Polisi Lalu Lintas Kota Semarang. Jurnal Kedokteran Diponegoro, 5(4), 495-503.

Natalia, D., Pratiwi, S. E., \& Fakihun, S. (2018). Prevalensi dan Identifikasi Jamur Penyebab Tinea Pedis Pada Satuan Polisi Pamong Praja Pontianak. Jurnal FKU Pontianak, 1, 35-50.

Pratama, K. F. (2017). GANGGUAN KULIT PEMULUNG DI TPA KENEP DITINJAU DARI ASPEK KESELAMATAN DAN KESEHATAN KERJA. The Indonesian Journal of Occupational Safety and Health, 6(2), 135-145.

Rustika, \& Agung, W. (2018).

KARAKTERISTIK PETUGAS PEMUNGUT SAMPAH DENGAN TINEA PEDIS DI TEMPAT PEMBUANGAN AKHIR (TPA) RAWA KUCING, KOTA TANGERANG. Jurnal Ekologi Kesehatan, 17(1), 11-19. 